\title{
Correlation between angioarchitectural characteristics of brain arteriovenous malformations and clinical presentation of 183 patients
}

\author{
Impacto das características angioarquiteturais das malformações arteriovenosas \\ cerebrais na apresentaçáo clínica: análise de 183 pacientes \\ Ulysses Caus BATISTA ${ }^{1,2}$, Benedito Jamilson Araujo PEREIRA' ${ }^{1}$, Andrei Fernandes JOAQUIM², \\ Helder TEDESCHI', Ronie Leo PISKE'
}

\begin{abstract}
Background: The correlation between angioarchitecture and clinical presentation of brain arteriovenous malformation (bAVM) remains a subject of debate. Objective: The main purpose of the present study was to assess the correlation between angioarchitectural characteristics of bAVM and clinical presentation. Methods: A retrospective review of all consecutive patients presenting a bAVM who underwent a cerebral angiography at Beneficencia Portuguesa Hospital in São Paulo between January 2006 and October 2016 was carried out. Patients were divided in five groups: group 1 - hemorrhage; group 2 - seizure; group 3 - headache; group 4 - progressive neurological deficits (PND); group 5 - incidental). Results: A total of 183 patients were included, with group 1 comprising 56 cases, group 249 cases, group 341 cases, group 428 cases, and group 59 cases. Regarding hemorrhage presentation, a statistical correlation was observed with female gender (P<0.02), Spetzler-Martin 3B $(P<.0015)$, and lesions with low flow $(P<0.04)$. A positive association was found between group 2 and age less than 36 years $(P<0.001)$, male sex $(P<0.018)$, presence of superficial lesions not classified as SM 3B $(P<0.002)$, presence of venous ectasia $(p<0.03)$, and arterial steal phenomenon $(P<0.03)$. Group 4 was associated with older age $(P<0.01)$. Conclusions: Angioarchitectural characteristics can be correlated with some clinical presentations as well as with some clinical data, making it possible to create predictive models to differentiate clinical presentations.
\end{abstract}

Keywords: Central Nervous System Vascular Malformations; Intracranial Arteriovenous Malformations; Seizures; Stroke.

\section{RESUMO}

Antecedentes: A correlação entre a angioarquitetura e a apresentação clínica da Malformação Arteriovenosa do cérebro (MAVc) permanece um assunto de debate. Objetivos: Correlacionar as características angioarquiteturais das MAVc com a apresentação clínica. Métodos: Estudou-se pacientes consecutivos atendidos no Hospital Beneficência Portuguesa-SP, entre 2006 a 2016. Após análise geral, criaram-se cinco grupos de acordo com a apresentação clínica: 1- Hemorragia; 2 - Epilepsia; 3 - Cefaléia; 4 - Déficit Neurológico Progressivo (DNP) e 5 - Incidental. Características epidemiológicas (clínica e topografia) e angioarquiteturais (Classificação de Spetzler-Martin Modificada - SMM; Fluxo intranidal; Aneurismas arteriais, intranidais e venosos; Ectasia venosa; Congestão venosa; "Roubo" arterial; Vascularização dural; Drenagem Venosa Profunda) foram analisadas. Resultados: 183 pacientes foram incluídos e analisados globalmente. Após essa etapa, foram divididos nos grupos: 1 - 56 casos (30,6\%); 2 - 49 casos (26,7\%); 3 - 41 casos (22,4\%); 4 - 28 casos (15,3\%) e 5 - 9 casos (4,9\%). Principais achados foram referentes a apresentação hemorrágica, na qual observamos correlação estatística positiva com o sexo feminino $(P<0,02)$, lesões classificadas como SMM 3B $(P<0,0015)$ e baixo fluxo $(P<0,04)$. Relacionado à epilepsia, encontramos significância estatística que possibilitou a correlação com pacientes com idade inferior a 36 anos $(P<0,001)$, sexo masculino ( $P<0,018)$, lesões superficiais $(P<0,002)$, presença de ectasia venosa $(P<0,003)$ e "roubo" arterial $(P<0,01)$. Pacientes com DNP se apresentam com idade superior aos demais $(P<0,01)$. Conclusões:Após análise multivariada, foi possível separar as MAV em grupos de acordo com as características angioarquiteturais, comprovando que algumas dessas características estão fortemente relacionadas a determinada manifestação.

Palavras-chave: Malformações Vasculares do Sistema Nervoso Central; Malformações Arteriovenosas Intracranianas; Convulsões; Acidente Vascular Cerebral.

\footnotetext{
'Hospital Beneficência Portuguesa, Departamento de Neurorradiologia Intervencionista, São Paulo SP, Brazil.

Universidade Estadual de Campinas, Departamento de Neurocirurgia, Campinas SP, Brazil.

UCB (D) https://orcid.org/0000-0002-5265-7405; BJAP (D) https://orcid.org/0000-0001-5871-6405; AFJ (1) https://orcid.org/0000-0003-2645-0483; HT (iD https://orcid.org/0000-0003-3347-3886; RLP (in memoriam)

Correspondence: Ulysses Caus Batista; Email: ulysses@neurocirurgiacapixaba.com.

Conflict of interest:There is no conflict of interest to declare.

Authors' contributions: UCB: Study concept and design, image analysis and acquisition of data; BJAP: Acquisition of data; AFJ: Acquisition of data and study supervision; HT: Critical revision of the manuscript for important intellectual content; RLP: Study concept and design, image analysis, study supervision and final revision.

Received on July 07, 2020; Received in its final form on November 13, 2020; Accepted on January 18, 2021.
} 


\section{INTRODUCTION}

Brain arteriovenous malformations (bAVM) are rare lesions, with an estimated annual incidence of 1/100,000 new cases per year, accounting for about $2 \%$ of all hemorrhagic cerebrovascular onsets ${ }^{1}$. According to Ondra et $\mathrm{al}^{2}$, patients present an annual bleeding rate of $3.0 \%$, with severe cumulative risk of morbidity (2.7\%/year) and an annual mortality rate of $1 \%$. In addition to the hemorrhage, these lesions may also cause epileptic seizures, headaches and/or progressive neurological deficits (PND). Lasjaunias et al suggested that these different forms of clinical presentations could be secondary to the location of the lesion and angioarchitectural characteristics of $\mathrm{bAVM}^{3}$. However, the correlation between angioarchitecture and bAVM clinical presentation remains a subject of debate ${ }^{4}$.

The main purpose of the present study was to assess the correlation of angioarchitectural characteristics of BAVM with the clinical presentation of patients at diagnosis.

\section{METHODS}

After obtaining approval from the Institutional Review Board (No. 59830715.0.0000.5483), we conducted a retrospective database review of all consecutive patients presenting a bAVM who underwent a cerebral angiography of the six intracranial vessels following the same protocol at Beneficencia Portuguesa Hospital in Sao Paulo (Sao Paulo, Brazil) between January 2006 and October 2016. Clinical and radiological data were collected.

\section{Inclusion criteria}

Inclusion criteria were patients aged $\geq 18$ years, with complete clinical, epidemiological, and angiographic data on hospital admission charts who were diagnosed with bAVM. All angiographies were performed by the lead author (RLP).

\section{Exclusion criteria}

Exclusion criteria were patients aged $<18$ years and those with incomplete data on admission charts. Other types of intracranial arteriovenous malformations (AVM) were excluded. In addition, patients who received any other prior treatment, such as surgery, embolization or radiosurgery, and therefore had alterations in the original AVM angioarchitecture, were also excluded.

\section{Epidemiological characteristics}

The following data were extracted from the database: age, sex, clinical presentation, and lesion topography.

\section{Clinical presentation}

Patients were classified into 5 groups according to the chief complaint that led to the examination: 1) intracranial hemorrhage, 2) seizures 3) persistent headache, 4) progressive neurological deficits (PND), and 5) incidental finding on image exam.

\section{Topography}

Lesions related to the cerebral cortex were classified as superficial AVMs, regardless of the lobe in which they were located or if they were corticoventricular. Malformations located in the basal ganglia (with exclusive nutrition of perforating branches) were classified as deep lesions. Those located in the cerebellum or in the brainstem were classified as posterior fossa $\mathrm{AVMs}^{5}$.

\section{Angioarchitectural characteristics}

The following angioarchitectural characteristics (Table 1) were analyzed:

\section{Modified Spetzler-Martin grading scale}

Although the literature usually follows the Spetzler-Martin Grading Scale (S-M $)^{6}$, we considered the modifications proposed by Oliveira et $\mathrm{al}^{1}$, who sub classified bAVM grade 3 of the S-M. In this study, we divided bAVM grade 3 into two groups: modified S-M 3A and S-M 3B. The bAVMs that received a total of three points for medium size ( 2 points), eloquent location ( 1 point) and only superficial venous drainage (0 points) were classified as $3 \mathrm{~A}$, whereas those that were small (1 point), located in eloquent areas (1 point), and a deep venous drainage (1 point) were classified as 3B. In Figure 1, we present an example of AVM grades $3 \mathrm{~A}$ and $\mathrm{B}$.

\section{Intralesional flow}

BAVMs were classified as high- or low-flow. High-flow referred to cases where opacification after contrast injection occurred only in the malformation without filling other normal branches of this territory. In low-flow lesions, other arteries of the same vascular territory were also opacified.

\section{Intranidal aneurysms}

These are aneurysmal formations located inside the nidus. All intranidal aneurysms were confirmed in more than one angiographic projection (Figure 2-A).

\section{Arterial aneurysms (not intranidal)}

Aneurysms not directly related to the nidus of the AVM were divided into two: flow-related aneurysms, which refer to the location at the arterial pathway supplying the AVM, and aneurysms not related to the main supply for the AVM ${ }^{7}$.

\section{Venous aneurysms}

These are localized aneurysmatic dilatations in a vein draining the lesion, which were confirmed by different angiographic projections (Figure 2-B).

\section{Venous ectasia}

This refers to a marked increase in the diameter of the vessel that drains the AVM associated with tortuosities (Figure 2-B) ${ }^{8}$. 
Table 1. Description of demographic and angioarchitectural characteristics analyzed in this study.

\begin{tabular}{|c|c|}
\hline Characteristics studied & Description \\
\hline Clinical presentation & $\begin{array}{l}\text { Five groups were created: 1) intracranial hemorrhage, 2) epileptic seizures, 3) persistent headache, 4) } \\
\text { progressive neurological deficits, 5) incidental finding on image exam. }\end{array}$ \\
\hline Topography & $\begin{array}{l}\text { Lesions related to cerebral cortex were classified as superficial AVMs; in the basal ganglia (exclusive } \\
\text { nutrition by perforating branches) as deep lesions. Those located in the cerebellum or in the brainstem } \\
\text { were classified as posterior fossa } \mathrm{AVMS}^{5} \text {. }\end{array}$ \\
\hline $\begin{array}{l}\text { Grade } 3 \text { Spetzeler-Martin scale } \\
\text { modified }\end{array}$ & $\begin{array}{l}\text { Grade } 3 \text { Spetzeler-Martin Scale was divided into two groups: grade } 3 \text { A and 3B. AVMs that received two } \\
\text { points for medium size, one point for eloquent location, and zero for superficial venous drainage were } \\
\text { classified as 3A. Those that were small ( } 1 \text { point), located in eloquent areas (1 point), and a deep venous } \\
\text { drainage (1 point) were classified as 3B (Figure 1). }\end{array}$ \\
\hline Intralesional flow & $\begin{array}{l}\text { Classified as high or low flow. High flow referred to cases where contrast opacification occurred only } \\
\text { in the malformation without filling other normal branches of this territory. In low-flow lesions, other } \\
\text { arteries of the same vascular territory were also opacified. }\end{array}$ \\
\hline Intranidal aneurysms & $\begin{array}{l}\text { Aneurysmal formation located inside the nidus and confirmed in more than one angiographic } \\
\text { projection (Figure 2-A). }\end{array}$ \\
\hline Venous aneurysms & $\begin{array}{l}\text { Aneurysmatic dilatations in a vein draining the lesion, confirmed by different angiographic projections } \\
\text { (Figure 2-B). }\end{array}$ \\
\hline Venous ectasia & Marked increase in the diameter and tortuosities of the vessel that drains the AVM (Figure 2-B) ${ }^{8}$. \\
\hline Venous congestion & Redirecting draining flow to other veins hindering normal brain-tissue drainage (Figure 2-C). \\
\hline Arterial steal & Insufficient filling of the normal branches at the same territory where the AVM are located. \\
\hline Dural vascularization & Participation of dural vessels supplying the AVM (Figure 2-D). \\
\hline Deep venous drainage & Direct drainage to the deep venous system (Figure 3$)^{9}$. \\
\hline
\end{tabular}

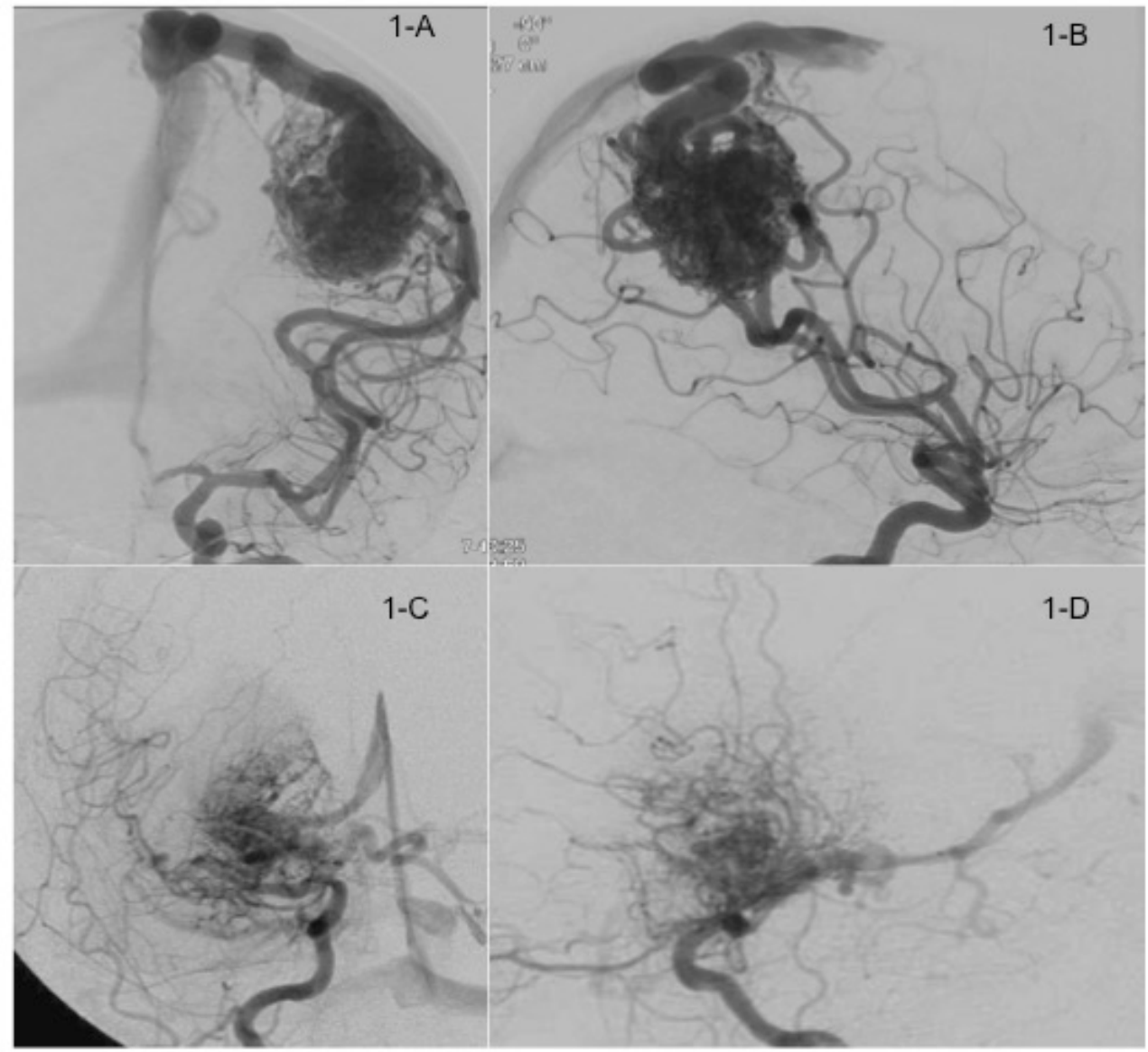

Figure 1. A: Left internal carotid artery angiogram, late arterial phase (frontal view), showing a medium (3 - $6 \mathrm{~cm}$ ) AVM in a superficial location with exclusive superficial venous drainage. B: Left internal carotid artery angiogram, late arterial phase (lateral view), of the same AVM in 1A, which was classified as 3A. C: Right internal carotid artery angiogram, late arterial phase (frontal view), showing a small (less than $3 \mathrm{~cm}$ ) AVM in the basal ganglia (deep location) with deep venous drainage; D: Right internal carotid artery angiogram, late arterial phase (lateral view) of the same AVM in 1C, which was classified as 3B. 


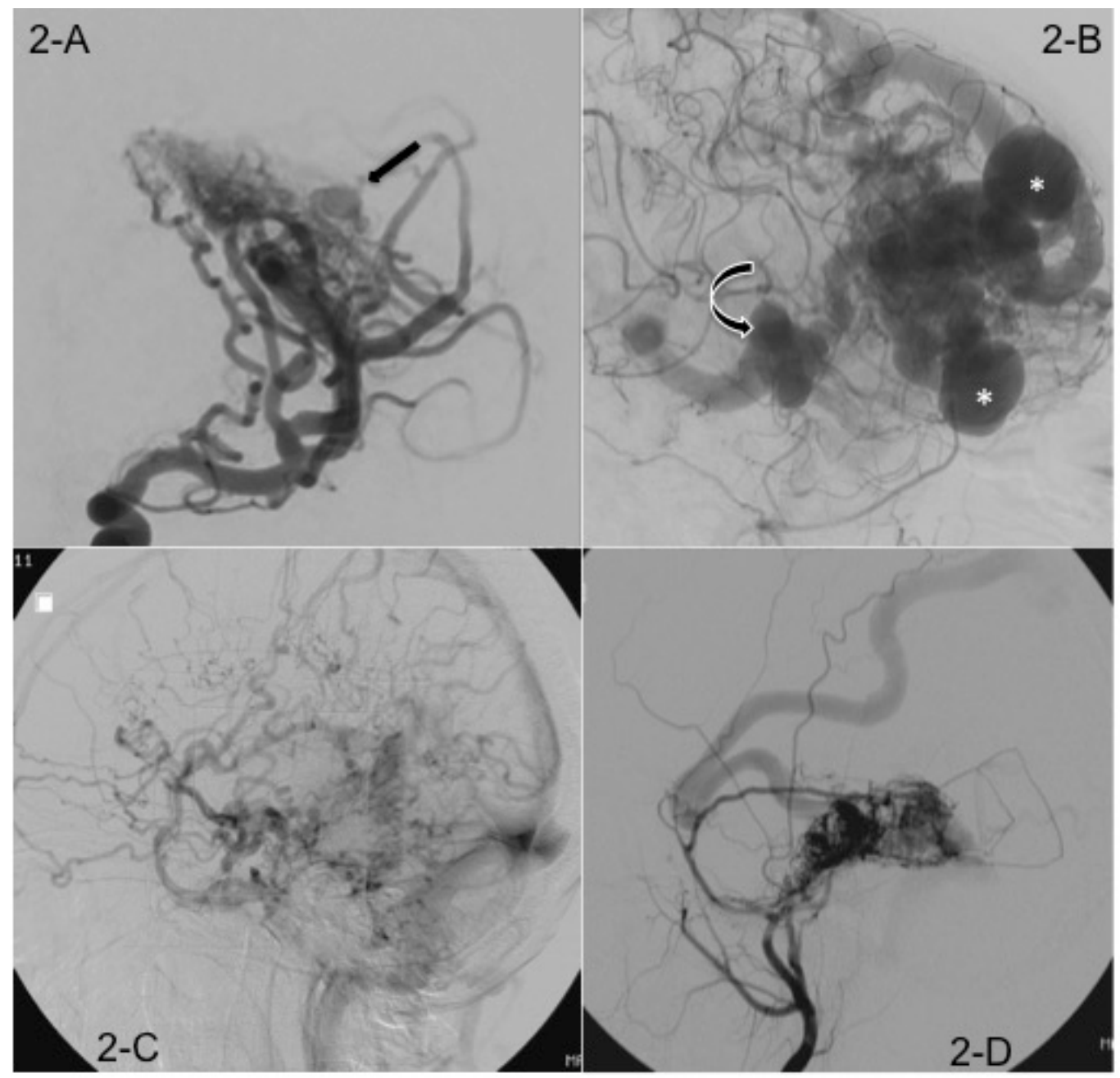

Figure 2. A: Left internal carotid artery angiogram, arterial phase in oblique view, highlighting an intranidal aneurysm (arrow); B: Left internal carotid artery, venous phase in lateral view, demonstrating two venous aneurysms (asterisk) and venous ectasia (curved arrow); C: Left internal carotid artery, late venous phase in lateral view, showing a venous congestion; D: Right external carotid angiogram, arterial phase in lateral view, demonstrating the dural vascularization of the AVM.

\section{Venous congestion}

This is the case when, in addition to the anatomically expected venous drainage, the flow is redirected to other veins, obstructing the normal drainage of brain tissue (Figure 2-C).

\section{Arterial steal}

This is related to a lack of filling of the normal branches of the same area where the AVM is located. These branches present retrograde filling by pial anastomoses, which could also supply the nidus.

\section{Dural vascularization}

This describes a situation in which the AVM is also supplied by dural vessels (Figure 2-D).

\section{Deep venous drainage}

All bAVMs presenting direct drainage to the deep venous system were included in this group (Figure 3$)^{9}$.

\section{Image acquisition}

All patients underwent a complete angiographic study, which consisted in the analysis of the internal and external carotid arteries and vertebral arteries, in at least anteroposterior and lateral views. Other views were analyzed to disclose arterial or venous stenosis or aneurysms. The angiographic equipments used were: Philips Integris biplane (between 2006 and 2014) and Philips Allura Xper FD biplane (between 2014 and 2016). Images were stored in the Aurora PACS system version 1.6.7. UCB and RLP researchers analyzed all images together.

\section{Statistical analysis}

Data were analyzed using the following softwares: SPSS V17, Minitab 16, and Excel Office 2010. Statistical resources used were equality of proportions test, Chi-Square test, odds ratio, and multivariate analysis by logistic regression. The logistic regression models were confirmed by the Pearson, deviance, and Hosmer-Lemeshow tests. The level of significance was set at $\mathrm{p}<0.05$. 


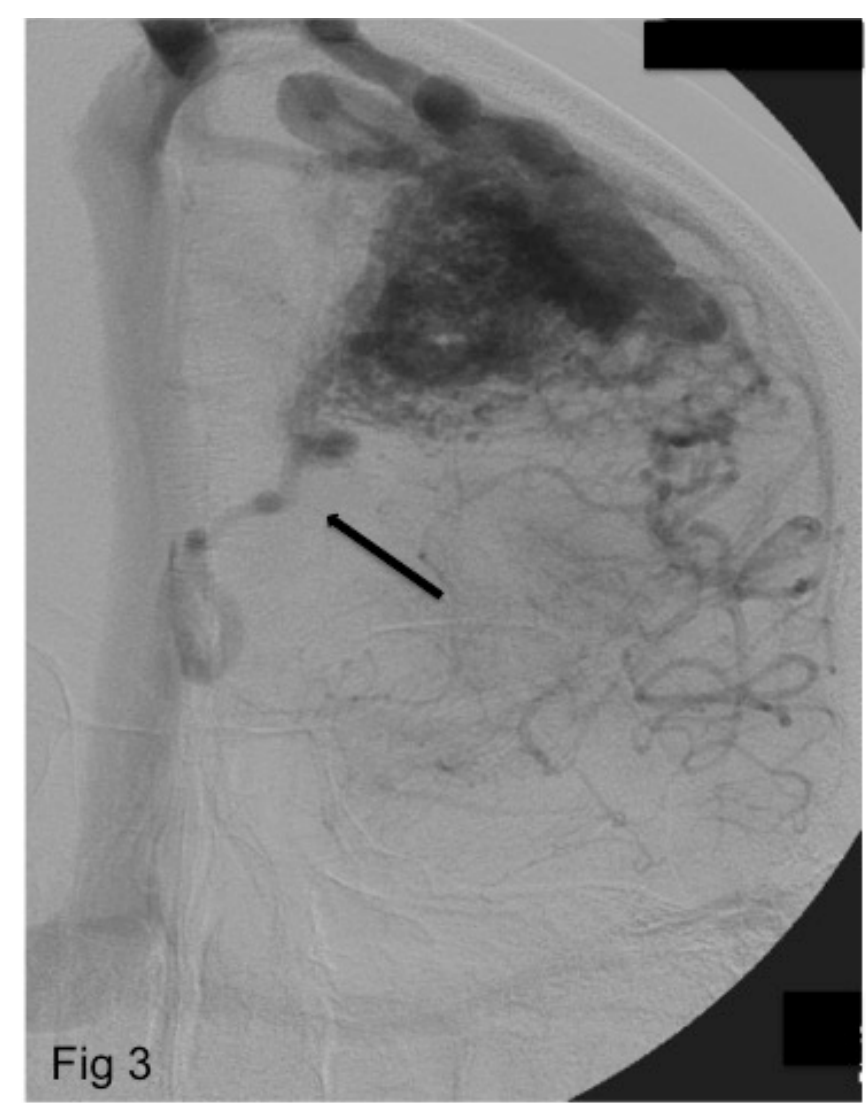

Figure 3. Left internal carotid angiogram, capillary phase (frontal view), showing a superficial AVM with deep venous drainage promoted by only one vessel (arrow). Although the major AVM drainage is done by superficial vessels, according to Spetzler-Martin Classification, the presence of this deep channel of drainage classifies this malformation as having deep venous drainage.

\section{RESULTS}

\section{Epidemiological analysis}

A total of 183 patients were included with 93 (50.8\%) males. The mean age of onset was 37 years (ranging from 18 to 84 years; SD: \pm 14.0 ).
Cases were divided into five groups according the clinical presentation at diagnostic: group 1 (hemorrhage): 56 cases (30.6\%); group 2 (seizure): 49 cases (26.7\%); group 3 (headache): 41 cases (22.4\%); group 4 (Progressive neurological deficits): 28 cases (15.3\%), and group 5 (Incidental): 9 cases (4.9\%).

Regarding the location of the lesions, superficial AVMs were the most common, with 124 cases (67.7\%), followed by the deep AVMs, with 36 cases (18.6\%) and by lesions located in the posterior fossa, with 23 cases (12.5\%). Table 2 summarizes these findings and the results for each group.

When comparing groups, a difference was found in the mean age of symptom onset between groups 2 and $4(\mathrm{P}<0.01)$ and 3 and $4(\mathrm{P}<0.01)$. The other groups did not differ in the mean age of onset.

Considering sex, a higher prevalence of bleeding was found in women while a higher prevalence of seizures was found in men $(\mathrm{P}<0.014)$. There was no statistical difference between sexes in the other groups.

The topography of the AVMs was also studied within each group, comparing the three possible locations, as shown in Table 1. There was a correlation between hemorrhage and deep lesions or lesions in the posterior fossa compared to superficial lesions ( $\mathrm{P}<0.0003$ and $\mathrm{P}<0.002$, respectively). An important difference was also observed in group 2 , in which patients with superficial AVMs had a higher incidence of epilepsy compared to patients with deep lesions $(\mathrm{P}<0.002)$. Differences were also observed between superficial and deep or posterior fossa AVMs in group 4, showing that superficial lesions presented more PND than lesions with other topographies $(\mathrm{P}<0.007$ and $\mathrm{P}<0.01$, respectively). No statistical differences were observed among patients who presented headaches. Table 3 summarizes all these findings.

The results of the epidemiological analysis of each group studied are presented:

- Group 1 (hemorrhage) - 56 patients: The mean age of this group was 37.5 years (ranging from 18 to 75 years; SD: \pm 11.97$)$, with $22(39.2 \%)$ males. In $24(42.8 \%)$ cases, the lesion had a superficial location, in 19 cases (33.9\%)

Table 2. Distribution of 183 patients according to demographic characteristics.

\begin{tabular}{|c|c|c|c|c|c|c|c|c|c|c|c|c|}
\hline $\begin{array}{l}\text { Demographic } \\
\text { characteristics }\end{array}$ & General & $\%$ & Hemorrhage & $\%$ & Seizure & $\%$ & Headache & $\%$ & PND & $\%$ & Incidental & $\%$ \\
\hline Mean age & 37 & & 37,5 & & 32 & & 34,5 & & 45,2 & & 45,4 & \\
\hline Maximum age & 84 & & 75 & & 55 & & 69 & & 71 & & 84 & \\
\hline Minimum age & 18 & & 18 & & 18 & & 18 & & 22 & & 19 & \\
\hline Standat deviation & 14 & & 12 & & 10,3 & & 13,5 & & 16,2 & & 22,5 & \\
\hline Male & 93 & 50.8 & 22 & 39.2 & 31 & 63.2 & 18 & 43.9 & 17 & 60.7 & 5 & 55.5 \\
\hline Female & 90 & 49.2 & 34 & 60.7 & 18 & 36.8 & 23 & 56.1 & 11 & 39.3 & 4 & 44.5 \\
\hline Superficial lesion & 124 & 67.7 & 25 & 44.6 & 46 & 93.9 & 32 & 75.6 & 17 & 60.7 & 4 & 44.4 \\
\hline Deep lesion & 36 & 18.6 & 19 & 33.9 & 3 & 6.1 & 6 & 14.6 & 6 & 21.4 & 2 & 22.2 \\
\hline $\begin{array}{l}\text { Posterior fossa } \\
\text { lesion }\end{array}$ & 23 & 12.5 & 12 & 21.4 & 0 & 0 & 3 & 7.3 & 5 & 17.8 & 3 & 33.3 \\
\hline Total & 183 & & 56 & & 49 & & 41 & & 28 & & 9 & \\
\hline
\end{tabular}


AVMs were deep and in the remaining 12 cases (21.4\%) AVMs were located in the posterior fossa. Deep and posterior fossa AVMs presented a higher incidence of hemorrhage than superficial AVMs $(\mathrm{P}<0.01)$.

- $\quad$ Group 2 (seizure) - 49 patients: The mean age of this group was 32 years (ranging from 18 to 55 years, SD: $\pm 10.37)$ and $31(63.2 \%)$ were male. In 46 (93.8\%) cases, lesions were located superficially, in three patients (6.2\%) AVMs were deeply located, and no patient who presented with epilepsy had lesions in the posterior fossa. Superficial AVMs had a higher incidence of epilepsy compared to deep AVMs $(\mathrm{P}<0.01)$.

- $\quad$ Group 3 (headache) - 41 patients: Patients in this group had a mean age of 34.5 years (ranging from 18 to 69 years, SD: \pm 13.5 ), 18 (44\%) of whom were male. The main location was superficial in 32 cases $(78 \%)$, followed by deep lesions with $10(14.6 \%)$ patients, and those located in the posterior fossa with seven (7.3\%) cases. There was no statistical difference between lesions locations in this group.

- Group4(progressive neurological deficits) - 28 patients: The mean age in this group was 45.2 years (range 22-71, SD: \pm 16$)$, and $17(60.7 \%)$ were male. Superficial lesions were the most frequent, with 17 (60.7\%) patients, followed by the deep AVMs and AVMs in the posterior fossa, with six (21.4\%) and five (17.8\%) cases, respectively. The superficial location correlated with neurological deficits compared to the other locations in this group $(\mathrm{P}<0.01)$.
- Group 5 (incidentals): 9 patients: Patients had a mean age of 45.4 years (ranging from 19-84 years; SD: \pm 22.5 ), with the male sex accounting for five (55.5\%) patients. The AVM were superficial in four $(44.4 \%)$ cases, deep in two $(22.2 \%)$ and located in the posterior fossa in three $(33.3 \%)$ cases.

\section{Angioarchitectural analysis}

The angioarchitectural characteristics of 183 bAVM were analyzed. The results for bAVMs as a total group and by subgroup are summarized in Table 3.

\section{Modified Spetzler-Martin classification}

AVM classified as SM 3B had a higher risk of bleeding than the other classifications ( $\mathrm{P}<0.0015$, OR: 3.82, 95\% CI, 1.70-8.57). In addition, patients in the epilepsy group were less likely to have a deep AVM ( $<$ 0.01; OR: 3.8; CI: 1.70 - 8.57 ).

\section{Study of AVM flow velocity}

Lesions with low flow were more susceptible to hemorrhage ( < 0.032; OR: 2.29; CI: 1.12 - 4.68) compared to the other groups.

\section{Presence of intranidal aneurysms}

The presence of intranidal aneurysms in AVM did not correlate with any clinical presentation $(\mathrm{P}=0.22)$.

\section{Arterial aneurysms}

High-flow aneurysms and aneurysms not related to highflow had an incidence of $22.4 \%$ and $7.1 \%$, respectively. The

Table 3. General and group distribution of the 183 MAVs in relation to the angioarchitectural characteristics studied.

\begin{tabular}{|c|c|c|c|c|c|c|c|c|c|c|c|c|}
\hline $\begin{array}{l}\text { Angioarchitectural } \\
\text { characteristics }\end{array}$ & General & $\%$ & Hemorrhage & $\%$ & Seizure & $\%$ & Headache & $\%$ & PND & $\%$ & Incidental & $\%$ \\
\hline SM 1 & 47 & 25.6 & 16 & 28.5 & 11 & 22.4 & 10 & 24.4 & 7 & 25 & 3 & 33.3 \\
\hline SM 2 & 61 & 33.3 & 13 & 23.2 & 17 & 34.6 & 21 & 42.8 & 10 & 35.7 & 2 & 22.2 \\
\hline mSM 3A & 30 & 16.3 & 7 & 12.5 & 11 & 22.4 & 8 & 19.5 & 4 & 14.3 & 1 & 11.1 \\
\hline mSM 3B & 30 & 16.3 & 17 & 30.3 & 2 & 4 & 3 & 7.3 & 6 & 21.4 & 2 & 22.2 \\
\hline SM 4 & 13 & 7.1 & 3 & 5.3 & 8 & 16.3 & 0 & 0 & 1 & 3.6 & 1 & 11.1 \\
\hline SM 5 & 2 & 1 & 0 & 0 & 1 & 2 & 0 & 0 & 1 & 3.6 & 0 & 0 \\
\hline High flow & 65 & 35.5 & 13 & 23.2 & 20 & 40.8 & 19 & 46.3 & 11 & 39.2 & 2 & 22.2 \\
\hline $\begin{array}{l}\text { Intranidal } \\
\text { aneurysms }\end{array}$ & 41 & 22.4 & 16 & 28.5 & 10 & 40.8 & 6 & 14.6 & 5 & 17.8 & 4 & 44.4 \\
\hline Venous aneurysms & 30 & 16.3 & 5 & 8.9 & 8 & 16.3 & 10 & 24.4 & 5 & 17.8 & 2 & 22.2 \\
\hline Venous ectasias & 26 & 14.2 & 5 & 8.9 & 12 & 24.5 & 2 & 4.9 & 7 & 25 & 0 & 0 \\
\hline $\begin{array}{l}\text { Venous } \\
\text { congestions }\end{array}$ & 39 & 21.3 & 9 & 16 & 9 & 18.3 & 10 & 24.4 & 9 & 32.1 & 2 & 22.2 \\
\hline $\begin{array}{l}\text { Arterial steal } \\
\text { phenomenon }\end{array}$ & 6 & 3.2 & 0 & 0 & 4 & 8.1 & 1 & 2.4 & 0 & 0 & 1 & 11.1 \\
\hline $\begin{array}{l}\text { Dural } \\
\text { vascularization }\end{array}$ & 13 & 7.1 & 4 & 7.1 & 5 & 10.2 & 3 & 7.3 & 0 & 0 & 1 & 11.1 \\
\hline $\begin{array}{l}\text { Deep venous } \\
\text { drainage }\end{array}$ & 64 & 34.9 & 25 & 44.6 & 13 & 26.5 & 9 & 22 & 13 & 46.4 & 4 & 44.4 \\
\hline Total & 183 & & 56 & & 49 & & 41 & & 28 & & 9 & \\
\hline
\end{tabular}


combination of cerebral aneurysm and AVM had an incidence of $29.5 \%$.

\section{Venous aneurysms}

There was no statistical correlation between the presence of venous aneurysms and the clinical presentation of patients $(\mathrm{P}=0.11)$.

\section{Venous ectasia}

The presence of venous ectasia did not show statistical correlation with hemorrhage ( $\mathrm{P}=0.31$; OR: 0.52; 95\% CI: 1.18-1.47). However, it was statistically significant in the epilepsy group (P = 0.03; OR: 2.77; 95\% CI: 1.18 - 6.53)

\section{Venous congestion}

The presence of venous congestion was not significantly correlated with clinical presentation $(\mathrm{P}=0.34)$.

Arterial "steal"

Arterial "steal" was significantly correlated with epilepsy $(\mathrm{P}=0.02)$.

\section{Dural vascularization}

There was no statistical significance between dural vascularization and the clinical presentation $(\mathrm{P}=0.76)$.

Deep venous drainage (DVD)

There was a correlation trend for DVD in the hemorrhage group $(\mathrm{P}<0.08)$.
Table 3 summarizes the results of the univariate analysis of angioarchitectural characteristics per group of patients.

\section{Correlation between high-flow AVM and other angioarchitectural characteristics}

Lesions with a high flow had a higher prevalence of intranidal aneurysms, venous ectasia, venous congestion and arterial "steal", as summarized in Table 4.

After univariate analysis, a multivariate logistic regression study was performed to evaluate the possibility of creating models that could predict the studied clinical presentations. We found a positive correlation between hemorrhage and female sex $(\mathrm{P}<0.02)$, AVM S-M 3B $(\mathrm{P}<0.001)$, and low flow $(\mathrm{P}<0.04)$.

In patients with epilepsy, we observed an association with age less than 36 years $(\mathrm{P}<0.001)$, male sex $(\mathrm{P}<0.018)$, superficial lesions not classified as SM 3B $(\mathrm{P}<0.002)$, presence of venous ectasia $(\mathrm{P}<0.03)$, and arterial "steal" phenomenon $(\mathrm{P}<$ 0.03). Predictive models could not be generated for the other groups. Table 5 summarizes these findings.

\section{DISCUSSION}

BAVMs are rare lesions, but they may have serious clinical consequences, such as intracranial hemorrhage ${ }^{1,8}$ that result in severe morbidity and even death ${ }^{2}$. In addition to hemorrhage, epileptic seizures, persistent headaches, and progressive neurological deficits are also associated with these lesions, which increase morbidity in these patients. Considering these points, evaluation of the AVM angioarchitecture is fundamental for the

Table 4. Univariate analysis of the AVM distribution according to the angioarchitectural characteristics and topography.

\begin{tabular}{|c|c|c|c|c|c|c|c|c|c|c|c|c|}
\hline \multirow{2}{*}{$\begin{array}{l}\text { Angioarchitectural } \\
\text { characteristics }\end{array}$} & \multicolumn{3}{|c|}{ Hemorrhage } & \multicolumn{3}{|c|}{ Seizure } & \multicolumn{3}{|c|}{ Headache } & \multicolumn{3}{|c|}{ PND } \\
\hline & $\mathrm{P}$ & OR & $\mathrm{Cl}$ & $P$ & OR & $\mathrm{Cl}$ & $\mathrm{P}$ & OR & $\mathrm{Cl}$ & $\mathrm{P}$ & OR & $\mathrm{Cl}$ \\
\hline $\begin{array}{l}\text { Superficial x deep } \\
\text { location }\end{array}$ & 0.0003 & 0.22 & $0.10-0.49$ & 0.002 & 6.48 & $1.88-22.34$ & 0.361 & 1.73 & $0.66-4.56$ & 0.0007 & 7.72 & $2.42-24.62$ \\
\hline $\begin{array}{l}\text { Superficial x PF } \\
\text { location }\end{array}$ & 0.0028 & 0.23 & $0.09-0.585$ & 0 & 0 & 0 & 0.29 & 2.31 & $0.64-8.32$ & 0.012 & 5.56 & $1.59-19.37$ \\
\hline Deep x PF location & 0.82 & 1.02 & $0.35-2.92$ & 0 & 0 & 0 & 0.995 & 1.33 & $0.29-5.95$ & 0.8845 & 0.72 & $0.19-2.70$ \\
\hline $\begin{array}{l}\text { Grade 3B mSM } \\
\text { scale }\end{array}$ & 0.0015 & 3.82 & $1.70-8.57$ & - & - & - & - & - & - & - & - & - \\
\hline Low flow & 0.032 & 2.29 & $1.12-4.68$ & 0.46 & 1.36 & $0.69-2.67$ & 0.144 & 1.8 & $0.88-3.65$ & 0.811 & 1.21 & $0.52-2.76$ \\
\hline $\begin{array}{l}\text { Intranidal } \\
\text { aneurysms }\end{array}$ & 0.25 & 1.63 & $0.78-3.37$ & 0.848 & 0.85 & $0.381-1.90$ & 0.25 & 0.52 & $0.20-1.35$ & 0.7 & 0.71 & $0.25-2.02$ \\
\hline Venous aneurysms & 0.11 & 0.4 & $0.14-1.10$ & 0.83 & 0.99 & $0.41-2.40$ & 0.18 & 1.96 & $0.83-4.62$ & 0.96 & 1.13 & $0.39-3.25$ \\
\hline Venous ectasias & 0.31 & 0.52 & $0.18-1.47$ & 0.03 & 2.77 & $1.18-6.53$ & 0.1 & 0.26 & $0.05-1.17$ & 0.109 & 2.53 & $0.94-6.80$ \\
\hline $\begin{array}{l}\text { Venous } \\
\text { congestions }\end{array}$ & 0.34 & 0.61 & $0.27-1.40$ & 0.7 & 0.78 & $0.34-1.78$ & 0.74 & 1.25 & $0.55-2.85$ & 0.204 & 1.97 & $0.81-4.79$ \\
\hline Arterial "steal" & 0 & 0 & 0 & 0.02 & 5.86 & $1.03-33.11$ & 0.87 & 0.68 & $0.07-6.03$ & 0 & 0 & 0 \\
\hline $\begin{array}{l}\text { Dural } \\
\text { vascularization }\end{array}$ & 0.76 & 1.00 & $0.29-3.42$ & 0.21 & 2.38 & $0.77-7.29$ & 0.77 & 1.04 & $0.27-3.97$ & 0 & 0 & 0 \\
\hline $\begin{array}{l}\text { Deep venous } \\
\text { drainage }\end{array}$ & 0.087 & 1.79 & $0.94-3.44$ & 0.191 & 0.58 & $0.28-1.19$ & 0.08 & 0.45 & $0.20-1.03$ & 0.25 & 1.75 & $0.77-3.95$ \\
\hline
\end{tabular}


Table 5. Multivariate analysis for the creation of predictive models for the clinical presentations studied (hemorrhage and epilepsy).

\begin{tabular}{|c|c|c|c|c|}
\hline \multirow{2}{*}{ Multivariate analysis } & \multicolumn{2}{|c|}{ Hemorrhage } & \multicolumn{2}{|c|}{ Seizure } \\
\hline & $P$ & OR (Cl 95\%) & $P$ & OR (Cl 95\%) \\
\hline Mean age & & & 0.001 & $0.95(0.92-0.98)$ \\
\hline Male & 0.021 & $0.45(0.23$ a 0.89$)$ & 0.018 & 2.46 (1.17 a 5.19) \\
\hline S-M 3B & 0.001 & 3.95 (1.69 a 9.2) & 0.002 & $0.08(0.01$ a 0.4$)$ \\
\hline High flow studied & 0.047 & 0.47 (0.22 a 0.99) & & \\
\hline \multicolumn{5}{|l|}{ Intranidal aneurysm } \\
\hline \multicolumn{5}{|l|}{ Venous aneurysm } \\
\hline Venous ectasia & & & 0.037 & $2.84(1.07$ a 7.56$)$ \\
\hline \multicolumn{5}{|l|}{ Venous congestion } \\
\hline Arterial steal phenomenon & & & 0.039 & $2.3(1.04$ a 5.1$)$ \\
\hline \multicolumn{5}{|l|}{ Dural vascularization } \\
\hline Deep venous drainage & & & & \\
\hline
\end{tabular}

management of these patients. Tong et al found that female sex correlated with hemorrhagic presentations, whereas men had a higher risk of epileptic seizures, which was similar to our findings ${ }^{10}$.

The mean age of symptom onset of our patients was similar to those found in the literature $\mathrm{1}^{11-14}$. However, pediatric patients are commonly included, which may affect the age of onset of patients with AVM. Hetts et al only studied adult patients, reporting a mean age of clinical symptoms of 42.6 years for patients with $\mathrm{AVM}^{15}$, slightly higher than our sample. We did not find studies that grouped the age of clinical presentation of AVM according to clinical presentation. In our study, we observed that PND patients were more advanced in age at the onset of symptoms than those patients with epilepsy or headaches $(P<.01)$. However, with regard to age, patients with hemorrhagic AVMs did not show any differences relative those from the other groups.

According to the literature ${ }^{16-18}$, deep AVMs have a higher rate of hemorrhage. Lesions classified as S-M 3B were also more related to hemorrhagic events than other lesions $(\mathrm{P}<0.01)$. The topography of the lesions was also studied within each group, showing that patients who had hemorrhagic events had deep or posterior fossa lesions ( $\mathrm{P}<0.003$ and $\mathrm{P}<0.00028$, respectively), with no differences between these two presentation sites $(\mathrm{P}>$ 0.82). In patients with epilepsy, lesions were predominantly superficial $(\mathrm{P}<0.002)$, as well as in patients with DNP, where superficial lesions predominated compared to deep-seated lesions or lesions located in the posterior fossa $(\mathrm{P}<0.0007$ and $\mathrm{P}<0.01$, respectively). This is probably a causative phenomenon, that is, the superficial location may increase the chances of cortical irritation with gliosis, leading to epileptic seizures ${ }^{6}$.

Kim et $\mathrm{al}^{19}$ and Duong et $\mathrm{al}^{20}$ studied predictive factors for hemorrhage in patients with AVMs, finding a correlation between exclusive deep-vein drainage and hemorrhagic presentation. However, according to Spetzler et $\mathrm{al}^{6}$, deep-vein drainage is characterized by at least one deep vessel. By considering lesions with exclusive deep-vein drainage, we found similar results $(\mathrm{P}<0.0015)$. However, if we maintained the original S-M classification of DVD, we found only a tendency for hemorrhage in patients with this type of drainage $(\mathrm{P}<$ 0.087). We believe that deeply located AVMs are more prone to hemorrhage and that the majority of deep-seated lesions cause deep-vein drainage.

Kubalek et al also reported that low-flow AVMs had a higher risk of hemorrhage, similar to our findings ( $\mathrm{P}>0.03$, OR 2.29, 95\% CI 1.12-4.68) $)^{12}$. Of note, the majority of AVMs that present bleeding are deep-seated, and high flow is not commonly found in that location.

Stapf et al reported a positive correlation between the presence of intranidal aneurysms and hemorrhagic events. ${ }^{21}$ However, Pollock et $\mathrm{al}^{22}$, in a study of 313 patients, did not report any relationship between the presence of intranidal aneurysm and hemorrhage, which was similar to our findings. Intranidal aneurysms were more frequently observed in lesions with high flow, suggesting that they are a secondary event, as observed in our series. Mast et al studied the correlation between arterial steal and DNP, and found no statistical significance between these characteristics ${ }^{23}$. However, we found this correlation in patients who presented epilepsy $(\mathrm{P}=0.02)$. It should be noted that, similar to intranidal aneurysms, this phenomenon is more prevalent in lesions with a high flow, which are also more commonly found in patients with epilepsy $(\mathrm{P}<0.03$, OR 10, 95\% CI 1.14-87.5).

Redekop et al and Kubalek et al reported that the incidence of hyperflow aneurysms in patients with bAVMs were $15.3 \%$ and $12.3 \%$, respectively ${ }^{7,12}$. In these two studies, it was found that the association of aneurysm and AVMs had an incidence of hemorrhage of about $7 \% /$ year $^{7}$. In our sample, we found a high incidence of these aneurysms (22.4\% of hyperflow aneurysms and $7.1 \%$ of non-hyperflow aneurysms). 
Shankar et al studied the effects of venous ectasia on cerebral AVMs, and, similar to our findings, observed that the ectasied drainage vessels showed a positive correlation with epilepsy $(\mathrm{P}<0.03 \text {, OR 2.77, 95\% CI, 1.18-6.53) })^{13}$.

Pan et al reported that vascularization by perforating arteries and exclusive deep-vein drainage presented a higher rate of hemorrhage ${ }^{17}$. It is interesting to note that in the study, the deep location of AVMs did not present positive results, even though the vascularization of perforating arteries and exclusive deepvein drainage are strongly related to this location. Kandai et al and Stefani et al also reported that the deep location of lesions is the main predictive characteristic for bleeding events ${ }^{16,18}$. In our study, the predictive model for hemorrhage showed that female gender $(\mathrm{P}<0.02)$, lesions classified as modified S-M 3B (small, deep, and with exclusively deep-vein drainage) $(\mathrm{P}<0.001)$ and low-flow AVMs $(\mathrm{P}<0.047)$ were associated with high risk of hemorrhage. These results are interesting, because they differ from those of epilepsy-related lesions, which have stronger association with younger age $(\mathrm{P}<0.004)$, male sex $(\mathrm{P}<0.03)$, superficial location $(\mathrm{P}<0.002)$, presence of venous ectasia $(\mathrm{P}$ $<0.03)$ and arterial steal phenomenon $(\mathrm{P}<0.03)$.

We concluded that angioarchitectural characteristics of bAVMs may be correlated with some clinical presentations as well as with some clinical data. Hemorrhagic events were associated with female sex, deep location, and low-flow AVMs. Epilepsy presentation was associated with younger age, male sex, superficial location, presence of ectasied veins, and arterial steal phenomenon. Posterior fossa lesions were not correlated with epilepsy in our series, and there was more frequent observation of PND in older patients.

\section{References}

1. Hernesniemi JA, Dashti R, Juvela S, Väärt K, Niemelä M, Laakso A. Natural history of brain arteriovenous malformations: a longterm follow-up study of risk of hemorrhage in 238 patients. Neurosurgery. 2008 Nov;63(5):823-9. https://doi.org/10.1227/01. NEU.0000330401.82582.5E

2. Ondra SL, Troupp H, George ED, Schwab K. The natural history of symptomatic arteriovenous malformations of the brain: a 24-year follow-up assessment. J Neurosurg. 1990 Sep;73(3):387-91. https:// doi.org/10.3171/jns.1990.73.3.0387

3. Lasjaunias P, Chiu M, ter Brugge K, Tolia A, Hurth M, Bernstein M. Neurological manifestations of intracranial dural arteriovenous malformations. J Neurosurg. 1986 May;64(5):724-30. https://doi. org/10.3171/jns.1986.64.5.0724

4. Mjoli N, Le Feuvre D, Taylor A. Bleeding source identification and treatment in brain arteriovenous malformations. Interv Neuroradiol. 2011 Sep 1;17(3):323-30. https://doi. org/10.1177/159101991101700307

5. Lv X, Wu Z, Jiang C, Yang X, Li Y, Sun Y, et al. Angioarchitectural characteristics of brain arteriovenous malformations with and without hemorrhage. World Neurosurg. 2011 Jul-Ago;76(1-2):95-9. https://doi.org/10.1016/j.wneu.2011.01.044

6. Spetzler RF, Martin NA. A proposed grading system for arteriovenous malformations. J Neurosurg. 1986 Oct;65(4):476-83. https://doi. org/10.3171/jns.1986.65.4.0476

7. Redekop G, TerBrugge K, Montanera W, Willinsky R. Arterial aneurysms associated with cerebral arteriovenous malformations: classification, incidence, and risk of hemorrhage.J Neurosurg. 1998 Oct;89(4):539-46. https://doi.org/10.3171/jns.1998.89.4.0539

8. Hirai S, Mine S, Yamakami I, Ono J, Yamaura A. Angioarchitecture related to hemorrhage in cerebral arteriovenous malformations. Neurol Med Chir (Tokyo). 1998;38 Suppl 38:165-70. https://doi. org/10.2176/nmc.38.suppl_165

9. Spetzler RF, Martin NA. A proposed grading system for arteriovenous malformations. J Neurosurg. 1986 Oct;65(4):476-83. https://doi. org/10.3171/jns.1986.65.4.0476

10. Tong X, Wu J, Lin F, Cao Y, Zhao Y, Ning B, et al. The effect of age, sex, and lesion location on initial presentation in patients with brain arteriovenous malformations. World Neurosurg. 2016 Mar;87:598606. https://doi.org/10.1016/j.wneu.2015.10.060

11. Gross BA, Du R. Natural history of cerebral arteriovenous malformations: a meta-analysis. J Neurosurg. 2013 Feb;118(2):43743. https://doi.org/10.3171/2012.10.JNS121280
12. Kubalek R, Moghtaderi A, Klisch J, Berlis A, Quiske A, Schumacher M. Cerebral arteriovenous malformations: influence of angioarchitecture on bleeding risk. Acta Neurochir (Wien). 2003 Dec;145(12):1045-52. https://doi.org/10.1007/s00701-003-0143-x

13. Shankar JJS, Menezes RJ, Pohlmann-Eden B, Wallace C, terBrugge K, Krings T. Angioarchitecture of brain AVM determines the presentation with seizures: proposed scoring system. AJNR Am J Neuroradiol. 2013 May;34(5):1028-34. https://doi.org/10.3174/ajnr.A3361

14. Sturiale CL, Rigante L, Puca A, Di Lella G, Albanese A, Marchese E, et al. Angioarchitectural features of brain arteriovenous malformations associated with seizures: a single center retrospective series. Eur J Neurol. 2013 May;20(5):849-55. https://doi.org/10.1111/ene.12085

15. Hetts SW, Cooke DL, Nelson J, Gupta N, Fullerton H, Amans MR, et al. Influence of patient age on angioarchitecture of brain arteriovenous malformations. AJNR Am J Neuroradiol. 2014 Jul;35(7):1376-80. https://doi.org/10.3174/ajnr.A3886

16. Kandai S, Abdullah MS, Naing NN. Angioarchitecture of brain arteriovenous malformations and the risk of bleeding: an analysis of patients in northeastern malaysia. Malays J Med Sci. 2010 Jan;17(1):44-8.

17. Pan J, Feng L, Vinuela F, He H, Wu Z, Zhan R. Angioarchitectural characteristics associated with initial hemorrhagic presentation in supratentorial brain arteriovenous malformations. Eur J Radiol. 2013 Nov;82(11):1959-63. https://doi.org/10.1016/j.ejrad.2013.05.015

18. Stefani MA, Porter PJ, terBrugge KG, Montanera W, Willinsky RA, Wallace MC. Angioarchitectural factors present in brain arteriovenous malformations associated with hemorrhagic presentation. Stroke. 2002 Apr 1;33(4):920-4. https://doi. org/10.1161/01.str.0000014582.03429.f7

19. Kim H, Salman RA-s, McCulloch CE, Stapf C, Young WL. Untreated brain arteriovenous malformation: patient-level meta-analysis of hemorrhage predictors. Neurology. 2014 Aug 12;83(7):590-7. https:// doi.org/10.1212/WNL.0000000000000688

20. Duong DH, Young WL, Vang MC, Sciacca RR, Mast H, Koennecke $\mathrm{HC}$, et al. Feeding artery pressure and venous drainage pattern are primary determinants of hemorrhage from cerebral arteriovenous malformations. Stroke. 1998 Jun 1;29(6):1167-76. https://doi. org/10.1161/01.str.29.6.1167

21. Stapf C, Mohr JP, Pile-Spellman J, Sciacca RR, Hartmann A, Schumacher $\mathrm{HC}$, et al. Concurrent arterial aneurysms in brain arteriovenous malformations with haemorrhagic presentation.J Neurol Neurosurg Psychiatry. 2002 Sep;73(3):294-8. https://doi. org/10.1136/jnnp.73.3.294 
22. Pollock BE, Flickinger JC, Lunsford LD, Bissonette DJ, Kondziolka D. Factors that predict the bleeding risk of cerebral arteriovenous malformations. Stroke. 1996 Jan 1;27(1):1-6. https://doi. org/10.1161/01.str.27.1.1
23. Mast H, Mohr JP, Osipov A, Pile-Spellman J, Marshall RS, Lazar $\mathrm{RM}$, et al. 'Steal' is an unestablished mechanism for the clinical presentation of cerebral arteriovenous malformations. Stroke. 1995 Jul 1;26(7):1215-20. https://doi.org/10.1161/01.str.26.7.1215 